\title{
Envisaging Constitutional Space for Aboriginal Governments
}

Kent McNeil

Osgoode Hall Law School of York University, kmcneil@osgoode.yorku.ca

Source Publication:

(1993-94) 19:1 Queen's Law Journal 95-136

Follow this and additional works at: https://digitalcommons.osgoode.yorku.ca/scholarly_works

Part of the Indian and Aboriginal Law Commons

\section{Recommended Citation}

Kent McNeil, "Envisaging Constitutional Space for Aboriginal Governments" (1993-94) 19:1 Queen's Law Journal 95-136.

This Article is brought to you for free and open access by the Faculty Scholarship at Osgoode Digital Commons. It has been accepted for inclusion in Articles \& Book Chapters by an authorized administrator of Osgoode Digital Commons. 


\title{
Envisaging Constitutional Space for Aboriginal Governments
}

\author{
Kent McNeil's
}

When the Supreme Court decided Sparrow, it could have interpreted s. 35 of the Constitution to give Aboriginal peoples absolute power over Aboriginal and treaty rights, a power which neither Parliament nor the Provinces could trump. Instead, the Court interpreted s. 35 to mean that Parliament could still infringe Aboriginal rights if the infringement could be justified by a strict test. Professor McNeil suggests that this interpretation does not originate in the constitutional text so much as in the British constitutional concepts of Parliamentary sovereignty and the rule of law. He argues that the Court maintained Parliament's power to regulate Aboriginal rights because it combined these constitutional concepts with an assumption that these rights are not effectively regulated by Aboriginal governments and laws. The Court's unarticulated fear was that an intolerable legal vacuum would be created if s. 35 was interpreted as excluding all federal regulatory power. The author argues, bowever, that to decolonize Canadian constitutional law, we must redefine Parliamentary sovereignty and the rule of law to include Aboriginal governments and laws, which could fill the constitutional space that s. 35 provided and avoid the vacuum that the Court feared.

\section{Introduction}

I. Parliamentary Infringement of Section 35(1) Rights

II. Foundations of the Canadian Constitution

III. A Constitutional Space for Self-Government

Conclusion

\section{Introduction}

The issue of Aboriginal self-government has moved from the periphery of constitutional debate to centre stage over the past twelve years. Prior to the patriation of the Canadian Constitution

\footnotetext{
* Valuable research assistance for this article was provided by Bernd Christmas, Lana Finney, Alexandra Mouland, and Robert Freedman. I would also like to thank the Social Sciences and Humanities Research Council of Canada for their financial support of this work, and Professors Michael Asch, Bruce Ryder, and Brian Slattery for very helpful comments and suggestions.
} 
in 1982, Aboriginal claims to a right of self-government generally did not receive serious consideration. The Eurocentric vision of two founding nations, and the constitutional dogma of exhaustive division of legislative powers in our federal system, simply left no place for Aboriginal governments in the minds of most nonAboriginal politicians and jurists. ${ }^{1}$

This began to change after the Constitution Act, 1982 was enacted, providing Canada with substantive protection for Aboriginal and treaty rights in s. 35:

35. (1) The existing aboriginal and treaty rights of the aboriginal peoples of Canada are hereby recognized and affirmed.

(2) In this Act, "aboriginal peoples of Canada" includes the Indian, Inuit and Métis peoples of Canada. ${ }^{2}$

1. See discussion in Kent McNeil, "The Decolonization of Canada: Moving Towards Recognition of Aboriginal Governments" [forthcoming].

2. An extensive body of literature on $\mathrm{s} .35$ has been produced since its enactment. See e.g.: Kenneth M. Lysyk, "The Rights and Freedoms of the Aboriginal Peoples of Canada (Ss. 25, 35 and 37)" in W. S. Tarnopolsky and G.-A. Beaudoin, eds., The Canadian Charter of Rights and Freedoms: Commentary (Toronto: Carswell, 1982) 467; Kent McNeil, "The Constitutional Rights of the Aboriginal Peoples of Canada" (1982) 4 Supreme Court L.R. 255 [hereinafter "Constitutional Rights of the Aboriginal Peoples"], and "The Constitution Act, 1982, Sections 25 and 35" [1988] 1 C.N.L.R. 1 [hereinafter "The Constitution Act, 1982"]; Douglas Sanders, "The Rights of the Aboriginal Peoples of Canada" (1983) 61 Can. Bar Rev. 314, and "Pre-Existing Rights: The Aboriginal Peoples of Canada (Sections 25 and 35)" in G.-A. Beaudoin and E. Ratushney, eds., The Canadian Charter of Rights and Freedoms, 2d ed. (Toronto: Carswell, 1989) 707; Brian Slattery, "The Constitutional Guarantee of Aboriginal and Treaty Rights" (1983) 8 Queen's Law Journal 232 [hereinafter "The Constitutional Guarantee"], "The Hidden Constitution: Aboriginal Rights in Canada" (1984) 32 Am. J. Comp. L. 361 [hereinafter "The Hidden Constitution"], "UnderstandingAboriginal Rights" (1987) 66 Can. Bar Rev. 727, and "First Nations and the Constitution: A Question of Trust" (1992) 71 Can. Bar Rev. 261 [hereinafter "First Nations and the Constitution"]; Norman Zlotkin, Unfinished Business: Aboriginal Peoples and the 1983 Constitutional Conference (Kingston: Institute of Intergovernmental Relations, 1983) at 37-46; Michael Asch, Home and Native Land: Aboriginal Rights and the Canadian Constitution (Toronto: Methuen, 1984) esp. at 1-8; James O'Reilly, "La Loi constitutionnelle de 1982: Droits des autochtones" (1984) 25 C. de D. 125; Georges Emery, "Réflexions sur le sens et la portée au Québec des articles 25, 35, et 37 de la Loi constitutionnelle de 1982" (1984) 25 C. de D. 145; Peter W. Hogg, Constitutional Law of Canada, 3d ed. (Toronto: Carswell, 1992) at 687-693; Justin Malbon, "Section 35, Canadian 
The next year, the House of Commons Special Committee on Indian Self-Government released its influential Penner Report, recommending that "the right of Indian peoples to self-government be explicitly stated and entrenched in the Constitution of Canada. ${ }^{13}$ During the four constitutional conferences held from 1983 to 1987 to try to identify and define s. 35(1) rights, the issue of constitutionally entrenching the right of self-government dominated the agenda. ${ }^{4}$ While no agreement was reached, federal and provincial leaders, and the public, were clearly informed that the issue was important to the Aboriginal peoples. This lesson was reinforced by the negative Aboriginal reaction to the Meech Lake Accord, which accommodated the demands of Québec while ignoring Aboriginal aspirations to have the legitimacy of their governments acknowledged in the Constitution. ${ }^{5}$

Constitution Act - The Aboriginal Right to Land" (LL.M. Thesis, Osgoode Hall Law School, 1987); William Pentney, "The Rights of the Aboriginal Peoples of Canada in the Constitution Act, 1982: Part II - Section 35: The Substantive Guarantee" (1988) 22 U.B.C. L. Rev. 207; Noel Lyon, "An Essay on Constitutional Interpretation" (1988) 26 Osgoode Hall L.J. 95, and "A Perspective on the Application of the Criminal Code to Aboriginal Peoples in Light of the Judgment of the Supreme Court of Canada in R. v. Sparrow" (1992) Special Ed. U.B.C. L. Rev. 306; Patrick Macklem, "Aboriginal Peoples, Criminal Justice Initiatives and the Constitution" (1992) Special Ed. U.B.C. L. Rev. 280. See also articles listed infra note 28.

3. Indian Self.Government in Canada: Report of the Special Committee (Ottawa: Supply and Services Canada, 1983).

4. On these conferences, see: Norman K. Zlotkin, "The 1983 and 1984 Constitutional Conferences: Only the Beginning" [1984] 3 C.N.L.R. 3; Bryan Schwartz, First Principles, Second Thoughts: Aboriginal Peoples, Constitutional Reform and Canadian Statescraft (Montreal: Institute for Research on Public Policy, 1986); David C. Hawkes, Aboriginal Peoples and Constitutional Reform: What Have We Learned? (Kingston: Institute of Intergovernmental Relations, 1989); and Kathy L. Brock, "The Politics of Aboriginal Self-Government: A Canadian Paradox" (1991) 34 Can. Pub. Admin. 272.

5. See: Louis Bruyere, "Aboriginal Peoples and the Meech Lake Accord" (1988) 5 Can. Hum. Rts. Y.B. 49; George Erasmus, "Twenty Years of Disappointed Hopes" in B. Richardson, ed., Drumbeat: Anger and Renewal in Indian Country (Toronto: Summerhill Press, 1989) 1 at 6-7 and 26-27; Geoffrey York, The Dispossessed: Life and Death in Native Canada (London: Vintage U.K., 1990) at 272-275; and J.R. Miller, Skyscrapers Hide the Heavens: A History of Indian-White Relations in Canada, rev. ed. (Toronto: University of Toronto Press, 1991) at 235. 
After the demise of the Meech Lake Accord, it was clear that constitutional renewal in Canada could not succeed without the participation of the Aboriginal peoples. The presence of the leaders of the four national Aboriginal organizations ${ }^{6}$ at the negotiating table with the first ministers was therefore essential during the next round of talks. As everyone knows, those talks resulted in the Consensus Report on the Constitution, agreed to at Charlottetown on August 28, 1992, by the leaders of the four Aboriginal organizations, the first ministers, and the two territorial leaders. The Charlottetown Accord would have led to recognition in the Constitution of the Aboriginal peoples' inherent right of self-government within Canada, with arrangements for implementation to be settled through further negotiations. ${ }^{7}$

The defeat of the Charlottetown Accord in the Referendum of October 26, 1992, seriously jeopardized the efforts to have Aboriginal self-government explicitly recognized in the Constitution. Although many people have said that the 'No' vote should not be interpreted as a rejection of self-government, political reality in the wake of the Referendum makes it unlikely that express constitutional recognition of that right will be

6. These organizations were: the Assembly of First Nations, representing most status Indians; the Native Council of Canada, representing mainly non-status Indians and some Métis; the Métis National Council, representing the Métis Nation in the prairie provinces; and the Inuit Tapirisat of Canada, representing the Inuit. Note, however, that some Aboriginal people claim not to be represented by any of these organizations. During the latest round of constitutional talks, for example, the Native Women's Association of Canada made this claim with respect to some issues affecting Aboriginal women. See: Sean Fine, "Native women aim to block national referendum in court" The [Toronto] Globe and Mail (13 October 1992) A8; Native Women's Association of Canada v. Canada, [1992] 4 C.N.L.R. 59 (F.C.T.D.), [1992] 4 C.N.L.R. 71 (F.C.A.); Native Women's Association of Canada v. Canada (1992), 57 F.T.R. 115 (F.C.T.D.), aff'd (1992), 145 N.R. 253 (F.C.A.). See also Michael Doxtater, "Failing to reach the Indian people: What is the democratic base of the Assembly of First Nations?" The [Toronto] Globe and Mail (5 November 1992) A19.

7. The Accord's provisions relating to Aboriginal peoples are outlined and discussed in McNeil, supra note 1 at 23-38. 
achieved in the near future. ${ }^{8}$ Other options exist, however. One is to pursue self-government outside the constitutional context, an approach which appears to be on the Aboriginal leaders' agendas. ${ }^{9}$ This approach could involve negotiated agreements with the federal, and some provincial, governments. ${ }^{10}$ Agreements of this sort, however, often involve delegated rather than inherent authority, making them unacceptable to many Aboriginal people. ${ }^{11}$ Moreover, unless included in land claims settlements, self-government agreements may not be constitutionally protected. ${ }^{12}$

8. Would a Québec premier, for example, be likely to agree to the constitutional aspirations of Aboriginal peoples without Québec's own requirements being met? Would British Columbia or Alberta agree without Senate reform? It may well be that one reason the constitutional conferences on Aboriginal issues in the $1980 \mathrm{~s}$ failed was that the federal and provincial governments had little to gain: see Brock, supra note 4 at 278 . The Charlottetown Accord was made possible because it was a compromise which gave something to everyone.

9. See Rudy Platiel and Geoffrey York, "Mercredi serves notice 'quiet revolution' to begin" The [Toronto] Globe and Mail (28 October 1992) A10; David Roberts, "Métis demand talks on self-rule" The [Toronto] Globe and Mail (29 October 1992) A4 (compare "Leader gets cool reception from Manitoba over bid to implement Metis Nation Accord" Victoria Times-Colonist (29 October 1992) A6).

10. The federal government appears to support this approach: see Rudy Platiel, "Powers shift to aboriginals, government says" The [Toronto] Globe and Mail (20 November 1992) A7.

11. The Sechelt Indian model of self-government, for example, has been criticized for this reason: see John P. Taylor and Gary Paget, "Federal/Provincial Responsibility and the Sechelt" in David C. Hawkes, ed., Aboriginal Peoples and Government Responsibility: Exploring Federal and Provincial Roles (Ottawa: Carleton University Press, 1989) 297 at 339-340.

12. If part of a land claims agreement, they are protected because s. 35(3) of the Constitution Act, 1982, added by the Constitutional Amendment Proclamation, 1983, (see SI/84-102) provides that, "For greater certainty, in subsection (1) 'treaty rights' includes rights that now exist by way of land claims agreements or may be so acquired." It can be argued that self-government agreements that are not contained in land claims agreements are treaties nonetheless, and as such are protected by subsection (1). The addition of subsection (3) in 1983 probably makes this argument less convincing, but support for it can be found in the principle of statutory interpretation that ambiguities - which certainly applies to the term "treaties" in s. 35(1) - are to be interpreted in favour of the Aboriginal peoples. See: Nowegijick v. Canada, [1983] 1 S.C.R. 29 at 36; Simon v. R., [1985] 2 S.C.R. 387 at 402; and R. v. Sparrow, [1990] 1 S.C.R. 1075 at 1107-1108 [hereinafter Sparrow], where the Supreme Court applied this principle directly to s. 35(1). 
Another option which Aboriginal leaders are considering is to unilaterally assert jurisdiction. ${ }^{13}$ This approach is consistent with self-government as an inherent right, but is certain to be challenged in court. When that happens, Aboriginal governments could either refuse to recognize the jurisdiction of Canadian courts, ${ }^{14}$ or claim that self-government is an Aboriginal and treaty right which is already entrenched in s. 35(1) of the Constitution Act, $1982 .{ }^{15}$

The issue of whether s. 35(1) recognizes and affirms a right of self-government has not been directly addressed by Canadian courts. ${ }^{16}$ However, judicial decisions have given the section some content, particularly by applying it to Aboriginal and treaty rights

13. See Geoffrey York, "Natives to move ahead with own laws" The [Toronto] Globe and Mail (20 November 1992) A5.

14. This could have serious consequences. During the stand-off at Oka/Kanesatake in 1990, the Canadian government clearly demonstrated that it was willing to use military force to impose jurisdiction on Aboriginal people who denied the authority of the Canadian state.

15. For Aboriginal expression of this view, see: Harold Cardinal, "Indian Nations and Constitutional Change" in J.A. Long and M. Boldt, eds., Governments in Conflict? Provinces and Indian Nations in Canada (Toronto: University of Toronto Press, 1988) 83 at 85-87; Gordon Peters, "Statement to the House of Commons Standing Committee on Aboriginal Affairs and Northern Development," Minutes of Proceedings and Evidence (3 March 1987) at 17: 5-7. A joint Aboriginal proposal at the 1987 constitutional conference confirmed this interpretation by proposing in part: "35(5)(a) For greater certainty, the inherent right of self-government . . . of all the Indian, Inuit and Métis peoples of Canada is recognized and affirmed in subsection (1)." See Assembly of First Nations, Native Council of Canada, Metis National Council, and Inuit Committee on National Issues, "Joint Aboriginal Proposal for Self-Government," (26-27 March 1987). For scholarly support, see Bruce Clark, Native Liberty, Crown Sovereignty: The Existing Aboriginal Right of Self-Government in Canada (Montreal: McGill-Queen's University Press, 1990); and "First Nations and the Constitution," supra note 2 at 279.

16. Some trial decisions have, however, denied the existence of an Aboriginal right of self-government in other contexts. See: Logan v. Styres (1959), 20 D.L.R. (2d) 416 (Ont. H.C.) [hereinafter Logan]; Ontario (A.G.) v. Bear Island Foundation, [1985] 1 C.N.L.R. 1 (Ont. S.C.) at 78 and 80 [hereinafter Bear Island]; Delgamuukw v. British Columbia (1991), 79 D.L.R. (4th) 185 (B.C.S.C.) especially at $452-454$ [hereinafter Delgamunkw]. However, as these are lower court decisions which did not take into account the effect of $s .35(1)$, the issue of whether that section includes a right of self-government must be regarded as open. 
to hunt and fish. ${ }^{17}$ The leading case is the decision of the Supreme Court of Canada in $R$. v. Sparrow, ${ }^{18}$ in which a member of the Musqueam Nation in British Columbia was charged for fishing with a drift net which exceeded the length allowed by the Musqueams' food fishing licence, issued pursuant to the federal Fisheries $A c t{ }^{19}$ The appellant contended that the licence's restrictions on net length were inconsistent with his Aboriginal right to fish, and were therefore invalid due to s. 35(1). In the unanimous opinion of the Court, delivered by Dickson C.J.C. and La Forest J., s. 35(1) provides constitutional protection to Aboriginal rights which were not extinguished prior to April 17, 1982, when the Constitution Act, 1982 was proclaimed in force. ${ }^{20}$ Prior to that, case law had established that these rights were generally subject to infringement and extinguishment by the Parliament of Canada. ${ }^{21}$ According to the Sparrow decision,

17. The main Court of Appeal decisions are: $R$. v. Eninew; $R$. v. Bear (1984), 10 D.L.R. (4th) 137 (Sask. C.A.); R. v. Hare and Debassige, [1985] 3 C.N.L.R. 139 (Ont. C.A.); R. v. Agawa, [1988] 3 C.N.L.R. 73 (Ont. C.A.), leave to appeal denied [1991] 1 C.N.L.R. vi (S.C.C.) [hereinafter Agawa]; R. v. Denny, [1990] 2 C.N.L.R. 115 (N.S.S.C.A.D.); R. v. Bombay, [1993] 1 C.N.L.R. 92 (Ont. C.A.) [hereinafter Bombay]. See also Re Tagornak Adoption Petition, [1984] 1 C.N.L.R. 185 (N.W.T.S.C.), where Marshall J. held that the customary adoption laws of an Aboriginal people are recognized and affirmed by s. 35(1). However, decisions involving s. 35(1) rendered before Sparrow, supra note 12, should be approached with caution, as they now must be read subject to the Supreme Court of Canada's decision in that case.

18. Supra note 12.

19. R.S.C. 1970 , c. F-14.

20. As the Sparrow case involved an Aboriginal right, the Court did not explicitly deal with treaty rights. However, as both Aboriginal and treaty rights receive the same protection in s. 35(1), their constitutional status should be the same. See e.g. Agawa, supra note 17; R. v. Flett (1989), 60 Man. R. (2d) 294 (Q.B.), leave to appeal denied [1991] 1 C.N.L.C. 140; R. v. Joseph, [1990] 4 C.N.L.R. 59 (B.C.S.C.); R. v. Littlewolf; R. v. Potts, [1992] 3 C.N.L.R. 100 (Alta. Q.B.), leave to appeal denied [1993] 1 C.N.L.R. vi; Bombay, supra note 17. While my discussion of s. 35(1) in the context of Sparrow will focus on Aboriginal rights, it should be kept in mind that the analysis is generally applicable to treaty rights as well.

21. See $R$. v. Derriksan (1976), 71 D.L.R. (3d) 159 (S.C.C.). On the vulnerability of treaty rights, see $R$. v. Sikyea (1964), 43 D.L.R. (2d) 150 (N.W.T.C.A.), aff'd [1964] S.C.R. 642; R. v. George, [1966] S.C.R. 267 [hereinafter George]; Daniels v. 
however, s. 35(1) did not entirely exclude the parliamentary power to infringe these rights by regulation. ${ }^{22}$ That power still exists, but due to the section it can only be exercised if the infringement can be justified under a test which the Supreme Court set out. ${ }^{23}$

White and the Queen, [1968] S.C.R. 517 [hereinafter Daniels]. Note, however, that Aboriginal rights may be protected in at least some parts of Canada by constitutional provisions in place before 1982: see e.g. discussion of the Rupert's Land and North-Western Territory Order in Kent McNeil, Native Claims in Rupert's Land and the North-Western Territory: Canada's Constitutional Obligations (Saskatoon: University of Saskatchewan Native Law Centre, 1982), and of the Royal Proclamation and other constitutional instruments in Clark, supra note 15.

22. As the Court did not expressly state that these rights could still be extinguished by federal legislation as well, this issue has been left in doubt. On the one hand, the clear distinction which the Court drew between regulation and extinguishment would seem to preclude the use of the regulatory power to effect an extinguishment: Sparrow, supra note 12 at 1097-1099. On the other, the Court said, at 1109, that "federal power must be reconciled with federal duty and the best way to achieve that reconciliation is to demand the justification of any government regulation that infringes upon or denies aboriginal rights [my emphasis]." Also, at 1119 , the Court seems to have envisaged the possibility of expropriation of an A boriginal right, which would raise the matter of compensation. If expropriation is equivalent to extinguishment, this may mean that a limited parliamentary power of extinguishment has survived the enactment of s. 35(1): see W.I.C. Binnie, "The Sparrow Doctrine: Beginning of the End or End of the Beginning?" (1990) 15 Queen's Law Journal 217 at 238-239; compare Hogg, supra note 2 at 692.

23. Prior to the coming into force of s. 35(1), Aboriginal rights (but not treaty rights) were to some extent subject to provincial legislation as well. See e.g.: Kruger v. R., [1978] 1 S.C.R. 104 [hereinafter Kruger]; Dick v. R., [1985] 2 S.C.R. 309; Jack and Charlie v. R., [1985] 2 S.C.R. 332 [herein after Jack and Charlie]; Kent McNeil, Indian Hunting, Trapping and Fishing Rights in the Prairie Provinces of Canada (Saskatoon: University of Saskatchewan Native Law Centre, 1983) at 11-19; Bruce Ryder, "The Demise and Rise of the Classical Paradigm in Canadian Federalism: Promoting Autonomy for the Provinces and First Nations" (1991) 36 McGill L.J. 308 at 362-380. Although Sparrow did not involve provincial legislation, the Court did say that s. 35(1) "affords aboriginal peoples constitutional protection against provincial legislative power": supra note 12 at 1105 . However, as the extent of that protection was not specified, uncertainty remains over whether the protection is absolute or subject to the same justificatory test as federal legislation. See: Slattery, "First Nations and the Constitution", supra note 2 at 284 285 , where it is argued convincingly that the test is not available to justify provincial legislation; Hogg, supra note 2 at 693, where the same conclusion is reached. See also Hydro-Quebec v. Canada (A.G.) and Coon Come, [1991] 3 C.N.L.R. 40 (Que. C.A.) at 59, and infra note 150. 
The Supreme Court's test for justification is as follows. Once it has been shown that Parliament has infringed an existing Aboriginal right, the party relying on the infringement has to prove two things. First, a valid legislative objective for the infringing legislation must be shown. Examples of valid objectives would include preserving Aboriginal rights by conserving and managing a resource, and protecting the public or Aboriginal peoples from the harmful exercise of those rights. However, a claim that the regulations were "in the public interest" would be too vague to qualify. If this initial burden is met, the second step in justifying an infringement involves proving that the legislation is as consistent as possible, in the circumstances, with constitutional recognition and affirmation of the right. The Supreme Court referred to a number of considerations which are relevant in deciding whether the legislation meets the required standard. To start with, "[t]he special trust relationship and the responsibility of the government vis-à-vis aboriginals must be the first consideration in determining whether the legislation or action in question can be justified." ${ }^{24}$ Other relevant questions include "whether there has been as little infringement as possible in order to effect the desired result; whether, in a situation of expropriation, fair compensation is available; and, whether the aboriginal group in question has been consulted with respect to the [particular] measures being implemented." 25 The objective of the analysis is to guarantee that the legislation "treat[s] aboriginal peoples in a way ensuring that their rights are taken seriously." ${ }^{\text {26 }}$ Broadly speaking, "recognition and affirmation requires sensitivity to and respect for the rights of aboriginal peoples on behalf of the government, courts and indeed all Canadians. ${ }^{17}$ In the context of Sparrow, recognition and affirmation of the Aboriginal right to fish for food and ceremonial purposes meant that federal regulations with the valid legislative objective of conservation had to give Aboriginal fishing for those purposes priority over sport and commercial fishing.

24. Sparrow, supra note 12 at 1114.

25. Ibid. at 1119.

26. Ibid.

27. Ibid.

K. McNeil 
The Sparrow decision raises a number of important Aboriginal rights issues which cannot be addressed here. ${ }^{28}$ Instead, this article is going to focus on two specific questions arising out of the decision. First, what prompted the Supreme Court to decide that the rights which are recognized and affirmed by s. 35(1) can still be infringed by Parliamentary regulation as long as the test of justification is met? Secondly, what are the implications of that aspect of the decision for First Nation self-government as a s. 35(1) right?

\section{Parliamentary Infringement of Section 35(1) Rights}

Section 35 is contained in Part II of the Constitution Act, 1982, after the Canadian Charter of Rights and Freedoms, which forms Part I of the Act. So s. 1 of the Charter, providing that the rights and freedoms set out in it are "subject only to such reasonable limits prescribed by law as can be demonstrably justified in a free and democratic society," does not apply to s. 35(1) rights. The Supreme Court acknowledged this in Sparrow. However, the Court went on to say that

this does not mean that any law or regulation affecting aboriginal rights will automatically be of no force or effect by the operation of s. 52 of the Constitution Act, 1982. Legislation that affects the exercise of aboriginal rights will nonetheless be valid, if it meets the test for justifying an interference with a right recognized and affirmed under s. 35(1)..$^{29}$

28. For commentary on the decision, see: Binnie, supra note 22; Patrick Macklem, "First Nations Self-Government and the Borders of the Canadian Legal Imagination" (1991) 36 McGill L.J. 382 at 445-450; Michael Asch and Patrick Macklem, "Aboriginal Rights and Canadian Sovereignty: An Essay on R. v. Sparrow" (1991) 29 Alta. L. Rev. 498; Frank Cassidy, "The Spirit of Sparrow: Aboriginal Rights and "The Honour of the Crown'" (March 1991) [unpublished]; David W. Elliott, "In the Wake of Sparrow: A New Department of Fisheries?" (1991) 40 U.N.B.L.J. 23; M.E. Turpel, "In Sparrow We Trust: Federal and Provincial Fiduciary Responsibilities" (1 November 1991) [unpublished]; Calvin D. Helin, "The Fishing Rights and Privileges of B.C.'s First Nations" [unpublished, no date]; Slattery, "First Nations and the Constitution," supra note 2 at 279-286.

29. Sparrow, supra note 12 at 1109 . Section 52(1) is reproduced infra note 33. 
The Supreme Court then created the test described 'above for assessing the validity of federal legislation, in terms which resemble but iare not identical to the terms of the s. 1 test the Court formulated in $R$. v. Oakes. ${ }^{30}$

My intention here is not to compare the Sparrow and Oakes: tests, but to try to explain why the Court felt compelled to invent such a test in Sparrow. Unlike s. 1, nothing in s. 35(1) invites the judicial branch to engage in balancing valid legislative objectives against constitutionally protected rights. ${ }^{31}$ Arguably, by placing s. 35 outside the Charter and thus beyond the reach of s. 1, the legislators intended to prevent just that sort of judicial activism. ${ }^{32}$ However, the Supreme Court made no attempt to explain the significance of the location of s. 35. Instead, after stating that "[ $t]$ here is no explicit language in the provision that authorizes this Court:or any court to assess the legitimacy of any government legislation that restricts aboriginal rights, ${ }^{133}$ the judges offered the following explanation for their interventionist approach:

30. [1986] 1 S.C.R. 103 [hereinafter Oakes]. For commentary on s. 1, see Pamela A. Chapman, "The Politics of Judging: Section 1 of the Charter of Rights and Freedoms" (1986) 24 Osgoode Hall L.J. 867; Sidney R. Peck, "An Analytical Framework for the Application of the Canadian Charter of Rights and Freedoms" (1987) 25 Osgoode Hall L.J. 1; Robin M. Elliot, "The Supreme Court of Canada and Section 1 - The Erosion of the Common Front" (1987) 12 Queen's Law Journal." 277; Lorraine Eisenstat Weinrib, "The Supreme Court of Canada and Section 1 of the Charter" (1988) 10 Supreme Court L.R. 469; Hogg, supra note 2 at 852-889.

31. See Clark, supra note 15 at 200-202.

32. Madam Justice B.M. McLachlin, in her article, "The Charter: A New Role for the Judiciary?" (1991) 29 Alta. L. Rev. 540, suggests that judges have been reluctantly forced by the Charter, in particular by s. 1, to make value judgments about legislation. But in the case of s. 35(1), it appears that the Supreme Court has willingly taken on such a role without the same obligation to do so.

33. Sparrow, supra note 12 at 1109 . This is a puzzling statement, for while it is true that s. 35(1) does not itself provide for judicial review of legislation restricting Aboriginal rights, s. 52(1) does impose such an obligation on the courts by providing: "The Constitution of Canada is the supreme law of Canada, and any law that is inconsistent with the provisions of the Constitution is, to the extent of the inconsistency, of no force or effect." In the passage from Sparrow accompanying supra note 29, the Court appeared to accept this application of s. 52(1). 
Yet, we find that the words "recognition and affirmation" incorporate the fiduciary relationship referred to earlier and so import some restraint on the exercise of sovereign power. Rights that are recognized and affirmed are not absolute. Federal legislative powers continue, including, of course, the right to legislate with respect to Indians pursuant to s. 91(24) of the Constitution Act, 1867. These powers must, however, now be read together with s. 35(1). In other words, federal power must be reconciled with federal duty and the best way to achieve that reconciliation is to demand the justification of any government regulation that infringes upon or denies aboriginal rights. ${ }^{34}$

This passage suggests that the words "recognized and affirmed" are insufficient to place Aboriginal rights completely beyond the reach of federal legislative power. What those words apparently do is prevent Parliament from breaching the fiduciary obligation which the Crown owes to the Aboriginal peoples. In another passage, the Court described the effect of s. 35(1) in these terms:

The way in which a legislative objective is to be attained must uphold the honour of the Crown and must be in keeping with the unique contemporary relationship, grounded in history and policy, between the Crown and Canada's aboriginal peoples. The extent of legislative or regulatory impact on an existing aboriginal right may be scrutinized so as to ensure recognition and affirmation. ${ }^{35}$

The Supreme Court offered little justification for interpreting the words "recognized and affirmed" as providing Aboriginal rights with only some protection, but not an absolute guarantee, against federal legislative infringement. Their interpretation should be compared with that of Professor Brian Slattery, who undertook an extensive examination of the meaning of the words "recognized and affirmed" before concluding:

When section 35 states that existing aboriginal and treaty rights are "hereby recognized and affirmed," it seems to mean that they are formally acknowledged as valid in law and rendered sure and unavoidable. ${ }^{36}$

34. Ibid. at 1109 .

35. Ibid. at 1110 .

36. Slattery, "The Constitutional Guarantee," supra note 2 at 252. See also Slattery, "The Hidden Constitution", supra note 2 at 380-385, where, subject to the qualification referred to below in text accompanying note 39 , Slattery fortified his interpretation of s. 35(1) with s. 35(4) (added by the Constitutional Amendment Proclamation, 1983, see SI/84-102). Section 35(4) reads: "Notwithstanding any other 
By "unavoidable" Slattery apparently meant that legislation which attempted either to nullify or restrict an Aboriginal right would be inconsistent with the recognition and affirmation of that right in the Constitution, and to that extent would be of no force or effect due to s. 52(1). ${ }^{37}$ However, in his later work Slattery suggested that s. 35 rights could be overridden in exceptional circumstances by federal legislation, but "only in emergencies, for pressing public need." ${ }^{38}$ Finally, in "Understanding Aboriginal Rights," an article which was relied upon extensively by the Supreme Court in Sparrow, Slattery retained the national emergency limitation and added two more qualifications, suggesting that s. 35 rights would also be subject to:

(1) regulations that operate to preserve or advance section 35 rights (as by conserving a natural resource essential to the exercise of such rights);

(2) regulations that prevent the exercise of section 35 rights from causing serious harm to the general populace or native peoples themselves (such as standard safety restrictions governing the use of fire-arms in hunting). ${ }^{39}$

It does not seem, however, that Slattery's apparent modification of his earlier views was based on a reinterpretation of the meaning of "recognized and affirmed." Instead, as a matter of policy he appears to have become concerned that Aboriginal rights to hunt and fish, for example, would be entirely unregulated if those views were adopted. After suggesting that one approach to s. 35(1) would be to hold that it "recognizes unextinguished aboriginal rights in their original form, so that any regulations restricting their exercise are invalid," he wrote:

provision of this Act, the aboriginal and treaty rights referred to in subsection (1) are guaranteed equally to male and female persons." As Slattery pointed out at 383, the "word 'guaranteed' is significant, because it plainly indicates an intent to entrench." In fact, the same word is used in s. 1 to entrench Charter rights.

37. Slattery, "The Constitutional Guarantee," supra note 2 at 254-262. Section 52(1) is reproduced supra note 33.

38. Slattery, "The Hidden Constitution," supra note 2 at 384. The override suggested by Slattery appears to be similar to the federal power under "Peace, Order, and good Government" in s. 91 of the Constitution Act, 1867 to impinge on provincial jurisdiction in national emergencies: see Hogg, supra note 2 at 452-462.

39. Slattery, "Understanding Aboriginal Rights," supra note 2 at 782.

K. McNeil 
This approach leads to extreme consequences. It suggests, for example, that regulations. implementing basic safety precautions in hunting, or protecting a rare species of animal might be invalid. It seems, moreover, inconsistent with the:word "existing," which suggests that the rights in question are affirmed in a contemporary form rather than in their primeval simplicity and vigour. ${ }^{40}$

The Supreme Court apparently shared this concern, but unlike Slattery gave a restrictive interpretation to the words "recognized and affirmed" in order to meet it. ${ }^{41}$ As I will explain in more detail later, I think the Supreme Court's approach to this matter had little to do with the actual words of s. 35(1), and a great deal to do with policy considerations and the Court's constitutional paradigm, with negative implications for Aboriginal sélfgovernment.

We have seen that the Supreme Court decided that s. 35(1) constitutionalized the fiduciary relationship between the Crown and the Aboriginal peoples. ${ }^{42}$ This does not appear to be because this relationship is itself an Aboriginal or treaty right. Rather, in the Court's view the general effect of the section is to elevate this historic relationship to a constitutional level, where it can be used to protect the rights that are recognized and affirmed against legislation which is unjustifiable because it violates the relationship. But where does this interpretation of s. 35 come from? There is no mention of this fiduciary relationship in s. 35. In fact, despite its historical roots in the Royal Proclamation of 1763 and the treaty-making process, the relationship was not even a recognized

40. Ibid. Slattery apparently thought that the presence of the word "existing" supported his policy argument. However, I see no inconsistency between affirming Aboriginal rights in their contemporary form, and exempting them from federal regulatory power, unless one interprets "existing" as preserving the federal regulatory power which existed prior to the enactment of s. 35(1), an interpretation which Slattery clearly rejected, at least in his earlier work. See "The Constitutional Guarantee," supra note 2 at 257-262, and "The Hidden Constitution," supra note 2 at 383.

41. On the effect of the word "existing," the Court relied on Slattery's interpretation, not to imply a limited federal regulatory power, but to reject the "frozen rights" approach to s. 35(1) which some lower courts had taken: Sparrow, supra note 12 at 1091-1093. In the Supreme Court's view, "existing" means "unextinguished:" ibid. at 1092.

42. For discussion of this aspect of the decision, see Turpel, supra note 28. 
legal concept in $1982 .{ }^{43}$ It first appeared on the scene as a major element in Aboriginal rights jurisprudence in 1984 when the Supreme Court decided Guerin v. Canada. ${ }^{44}$ But while seven out of eight judges in that case found that the Crown has a fiduciary obligation to the Aboriginal peoples, Dickson J. and three others appear to have regarded the obligation as arising in a legal sense only upon a surrender of Indian lands to the Crown. ${ }^{45}$ The idea that the Crown has a broad fiduciary obligation to the Aboriginal peoples in all its dealings with them was first expressed by the Supreme Court in the Sparrow decision. ${ }^{46}$

One might wonder, then, how the Canadian legislators who proposed the Constitution Act, 1982, and the British legislators who enacted it, could have intended s. 35 to constitutionalize a fiduciary relationship which no one at the time knew existed.

43. Discussion of the concept is generally absent from the academic literature on s. 35 published prior to Guerin v. Canada, [1984] 2 S.C.R. 335 [hereinafter Guerin]; see articles listed supra note 2. See also Maureen Ann Donohue, "Aboriginal Land Rights in Canada: A Historical Perspective on the Fiduciary Relationship" (1990) 15 Am. Indian L. Rev. 369, especially at 382-387.

44. Supra note 43. See discussion in: Richard Bartlett, "You Can't Trust the Crown. The Fiduciary Obligation of the Crown to the Indians: Guerin v. The Queen" (1985) 49 Sask. L. Rev. 367; John D. Hurley, "The Crown's Fiduciary Duty and Indian Title: Guerin v. The Queen" (1985) 30 McGill L.J. 559; D. Paul Emond, "Case Comment: Guerin v. R." (1986) 20 E.T.R. 61; William R. McMurtry and Alan Pratt, "Indians and the Fiduciary Concept, Self-Government and the Constitution: Guerin in Perspective" (1986) 3 C.N.L.R. 19; and Darlene Johnston, "A Theory of Crown Trust towards Aboriginal Peoples" (1986) 18 Ottawa L. Rev. 307.

45. Guerin, supra note 43 at 375-387. Wilson J. and two others thought the obligation existed before surrender, but they nonetheless related it directly to Indian lands: ibid. at $348-350$.

46. Supra note 12 at 1108: "In our opinion, Guerin, together with $R$. v. Taylor and Williams (1981), 34 O.R. (2d) 360, ground a general guiding principle for $s$. 35(1). That is, the Government has the responsibility to act in a fiduciary capacity with respect to aboriginal peoples. The relationship between the Government and aboriginals is trust-like, rather than adversarial, and contemporary recognition and affirmation of aboriginal rights must be defined in light of this historic relationship." Note that the aspect of Taylor and Williams relied on by the Supreme Court in Sparrow was that, in interpreting Indian treaties, courts must keep in mind that "the honour of the Crown is always involved and no appearance of 'sharp dealing' should be sanctioned": 34 O.R. (2d) 360 at 367. 
Admittedly, what matters in the context of statutory interpretation is not the actual intention of the legislators, but the legislative objective or purpose behind the statute. ${ }^{47}$ In Sparrow, the Supreme Court took a purposive approach to s. 35, acknowledging that it "represents the culmination of a long and difficult struggle in both the political forum and the courts for the constitutional recognition of aboriginal rights." ${ }^{48}$ The approach to be taken in interpreting it, the Court said, "is derived from general principles of constitutional interpretation, principles relating to aboriginal rights, and the purposes behind the constitutional provision itself." 49 Moreover, "[w]hen the purposes of the affirmation of aboriginal rights are considered, it is clear that a generous, liberal interpretation of the words in the constitutional provision is demanded." 50 However, an examination of the Court's discussion of actual legislative purpose reveals little beyond a general desire to protect rights, which in the past "were often honoured in the breach," from legislative infringement. ${ }^{51}$ The Court did not suggest there was evidence of an intention to entrench a fiduciary relationship.

The question which remains unanswered is this: Given the legislative purpose to constitutionalize Aboriginal rights, and the desire to give s. 35(1) "a generous, liberal interpretation," 52 why did the Supreme Court decide that those rights are still subject to justifiable federal legislation? Why do "[f]ederal legislative powers continue, including, of course, the right to legislate with respect to Indians pursuant to s. 91(24) of the Constitution Act, 1867"? ?33

A simple answer might be that the legislators who amended Canada's Constitution in 1982 would have repealed s. 91(24) if they had intended Aboriginal rights to be immune from infringement

47. See T.R.S. Allan, "Legislative Supremacy and the Rule of Law: Democracy and Constitutionalism" (1985) 44 Cambridge L.J. 111 at 117-118.

48. Supra note 12 at 1105.

49. Ibid. at 1106 .

50. Ibid.

51. Ibid. at 1102-1110, quoted words at 1103 .

52. Ibid. at 1106.

53. Ibid. at 1109 . See quote in text above, at note 34 . 
by federal legislation. In other words, s. 91(24) would have no work to do if Parliament could no longer legislate regarding Aboriginal rights. ${ }^{54}$ But on closer examination, this explanation is insufficient. Nothing in s. 35(1) prevents Parliament from enacting legislation involving Aboriginal rights. Instead, it can be interpreted as barring Parliament from infringing Aboriginal rights, while leaving intact Parliament's jurisdiction to enact legislation protecting or enhancing Aboriginal rights, for example by ratifying a land claim agreement to which an Aboriginal people has freely consented. Section 91(24) of the 1867 Act and s. 35 of the 1982 Act must be read together in a purposive way that enhances Aboriginal rights, in much the same way as ss. 91 and 92 of the 1867 Act must generally be read together with, and in a way that promotes, Charter rights, but with this major difference: s. 35 rights are not subject to the qualification which s. 1 places on Charter rights.

So I do not think that looking to s. 91(24) can provide an explanation for why the Supreme Court decided that federal power over Aboriginal rights continues, any more than the actual words of s. 35, or the legislative purpose and principles of construction, can explain the court's decision. However, an explanation can perhaps be glimpsed in the following passage from Sparrow:

The constitutional recognition afforded by the provision therefore gives a measure of control over government conduct and a strong check on legislative power. While it does not promise immunity from government regulation in a society that, in the twentieth century, is increasingly more complex, interdependent and sophisticated, and where exhaustible resources need protection and management, it does hold the Crown to a substantive promise. The government is required to bear the burden of justifying any legislation that has some negative effect on any aboriginal right protected under s. 35(1) [my emphasis]. ${ }^{55}$

The emphasised words are a modified version of the more explicit language used by the British Columbia Court of Appeal in $R$. v. Sparrow to arrive at the same conclusion:

54. See Slattery, "First Nations and the Constitution", supra note 2 at 282-283.

55. Supra note 12 at 1110 .

K. McNeil 
The constitutional recognition of the right to fish cannot entail restoring the relationship between Indians and salmon as it existed 150 years ago. The world has changed. The right must now exist in the context of a parliamentary system of government and a federal division of powers. It cannot be defined as if the Musqueam band had continued to be a self-governing entity, or as if its members were not citizens of Canada and residents of British Columbia. Any definition of the existing right must take into account that it exists in the context of an industrial society with all of its complexities and competing interests. The "existing right" in 1982 was one which had long been subject to regulation by the federal government. It must continue to be so because only government can regulate with due regard to the interests of all [my emphasis]. ${ }^{56}$

In the view of the Court of Appeal, the constitutional right to fish could not be regulated by self-governing Aboriginal peoples. Lack of faith in the capacity of Aboriginal peoples to govern the exercise of their rights is also implicit in the Supreme Court's decision. Counsel for Sparrow argued that, due to s. 35(1), authority to regulate an Aboriginal right inheres in the people holding the right, as "the right to regulate is part of the right to use the resource." ${ }^{57}$ Counsel speculated that federal regulations might nonetheless be applicable, but only in exceptional circumstances,

where for example such measures were necessary to prevent serious impairment of the aboriginal rights of present and future generations, where conservation could only be acheived by restricting the right and not by restricting fishing by other users, and where the aboriginal group concerned was unwilling to implement necessary conservation measures [my emphasis]. ${ }^{58}$

The Supreme Court did not address the argument in favour of self-regulation directly. However, the Court's view of the matter

56. (1986), 36 D.L.R. (4th) 246 (B.C.C.A.) at 272.

57. Supra note 12 at 1102 . For another way of phrasing this argument, see Asch and Macklem, supra note 28 at 506: "The right to fish was viewed by the Court [in Sparrow] as a right because of its centrality to Musqueam culture. If fishing is central to the Musqueam Nation, the ability to determine how this activity will be carried out on Musqueam lands, between the Musqueam and others, and among the Musqueam themselves, must also be central to its self-definition. That is, the ability to pass laws or rules governing how the practice of fishing is to occur, under the theory of aboriginal right adopted by the Court in Sparrow, equally ought to qualify as an aboriginal right under s. 35(1)."

58. Supra note 12 at 1102. 
may be revealed in the following words, expressed almost immediately after the passage just quoted:

It is worth recalling that while British policy towards the native population was based on respect for their right to occupy their traditional lands, a proposition to which the Royal Proclamation of 1763 bears witness, there was from the outset never any doubt that sovereignty and legislative power, and indeed the underlying title, to such lands vested in the Crown. ${ }^{59}$

So the standard denial of the inherent right of the Aboriginal peoples to govern themselves, a denial imbedded in Canadian constitutional law, ${ }^{60}$ appears to have been the Supreme Court's starting point for assessing the effect of s. 35(1). It seems that the Court was reluctant to alter the legislative power structure of Canada by interpreting the section as creating a constitutionally protected space for Aboriginal governments. ${ }^{61}$ The Court's conclusion that "[f]ederal legislative powers continue"62 therefore should have come as no surprise.

In order to understand the judicial mindset which led to this conclusion, I think it is necessary to examine the principles underlying the Canadian Constitution. We have already observed that Aboriginal governments were denied any constitutional status in Canada prior to the Constitution Act, 1982. This denial is deeply rooted in colonial attitudes, and a vision of the Canadian Constitution which has been nurtured by British traditions. The Constitution Act, 1982 could have changed that dramatically with

59. Ibid. at 1103. This passage should be compared with Quebec (A.G.) v. Sioui, [1990] 1 S.C.R. 1025 [hereinafter Sioul], decided just one week before Sparrow, where the Supreme Court at 1052-1053 said that, at least up to 1760, both France and Britain maintained relations with the Indian Nations "very close to those maintained between sovereign nations." In light of Sioui, it is possible that the Court in Sparrow intended only to assert the Crown's overarching sovereignty, rather than to deny any internal right of self-government to the Aboriginal peoples. However, the tenor of the Sparrow decision provides scant support for such an interpretation.

60. See McNeil, supra note 1.

61. See Macklem, supra note 28 at 449-453; and Asch and Macklem, supra note 28, especially at 506-508.

62. Supra note 12 at 1109 (see text accompanying supra note 34).

K. McNeil 
respect to the rights of the Aboriginal peoples. If the Supreme Court had decided that s. 35(1) shielded Aboriginal rights from any attempt by Parliament or the provincial legislatures to infringe or extinguish them, ${ }^{63}$ the section would necessarily have created a constitutional space for the Aboriginal peoples to govern the exercise of those rights themselves. In my view, a major reason why the Court did not do that is because colonialism, and British constitutionalism, still exert considerable influence over judicial thinking in the context of Aboriginal rights. ${ }^{64}$

\section{Foundations of the Canadian Constitution}

The preamble to the Constitution Act, $1866^{75}$ states that Canada shall have "a Constitution similar in Principle to that of the United Kingdom." The Act does not specify what that means, nor does it contain any other statement of the general principles underlying the Canadian Constitution. Indeed, it is a rather technical document, providing Canada with a federal system of government with legislative powers divided between Parliament and the provincial legislatures, without any of the high-sounding rhetoric commonly found in other constitutions. To find the principles on which the Canadian Constitution is based, one therefore has to go behind the Constitution Act, 1867 and examine the British Constitution.

A guiding principle of the British Constitution is the doctrine of parliamentary sovereignty or supremacy. ${ }^{66}$ This concept

63. I have argued in the past that this is the way s. 35(1) should be interpreted: see "Constitutional Rights of the Aboriginal Peoples" and "The Constitution Act, 1982," supra note 2.

64. For affirmation of this view in relation to judicial treatment of matrimonial property issues on Indian reserves, see Mary Ellen Turpel, "Home/Land" (1991) 10 Can. J. Fam. Law 17.

65. (U.K.), $30 \& 31$ Vict., c. 3.

66. Both terms appear in the literature, with some writers preferring "sovereignty" and others "supremacy:" see discussion in Stanley de Smith and Rodney Brazier, Constitutional and Administrative Law, 6th ed. (London: Penguin Books, 1986) at 64-65. 
developed out of centuries of struggle between the Crown and the House of Commons, culminating in the seventeenth century with the over-throw of the Stuarts, and the acceptance of the rule that the Crown is subject to Parliament, the supreme law-making author-ity. ${ }^{67}$ The power of the Crown, which at one time had been virtually absolute, was gradually diminished to a residual prerogative, exercisable most prominently in the area of foreign affairs. $^{68}$

With the triumph of Parliament, the idea that there are no legal restrictions on its legislative power came to dominate British constitutional thought. ${ }^{69}$ Earlier judicial dicta that Parliament could not legislate contrary to common right and reason ${ }^{70}$ were no longer regarded as good law. ${ }^{71}$ At a more theoretical level, this change in thinking was reflected in a jurisprudential shift away from natural law concepts of fundamental rights to legal positivism. ${ }^{72}$ By the mid-nineteenth century, the view that law is the command of the sovereign was prevalent. ${ }^{73}$ Since Parliament

67. See: ibid. at 70-73; R.F.V. Heuston, Essays in Constitutional Law, 2d ed. (London: Stevens \& Sons, 1964) at 58-81; and E.C.S. Wade and A.W. Bradley, Constitutional and Administrative Law, 10th ed. (London: Longmans, 1985) at 60-63.

68. See Wade and Bradley, ibid. at 245-255; de Smith and Brazier, supra note 66 at $127-138$.

69. Of course there are practical limitations, recognized in DeLolme's famous statement that "[i]t is a fundamental principle with Engish lawyers, that Parliament can do everything but make a woman a man, and a man a woman:" quoted in A.V. Dicey, Introduction to the Study of the Law of the Constitution, 9th ed. (London: Macmillan, 1939) at 43.

70. Dr. Bonham's Case (1610), 8 Co. Rep. 113 at 118 . See also Day v. Savadge (1614), Hob. 85 at 87 , where it was said that Parliament could not "make a man Judge in his own case."

71. See de Smith and Brazier, supra note 66 at 71-72; and Geoffrey Marshall, Parliamentary Sovereignty and the Commonwealth (Oxford: Clarendon Press, 1957) at $68-71$.

72. As de Smith and Brazier wrote, Blackstone's "lip-service to the primacy of natural law" in 1765 was but a faint echo of earlier views which "had long since ceased to have legal significance; for the judges had tacitly accepted a rule of obligation to give effect to every Act of Parliament, no matter how preposterous its content:" de Smith and Brazier, supra note 66 at 72.

73. John Austin was, of course, the leading proponent of this view, but Jeremy Bentham and others had laid the foundations for positivist theory before him.

K. McNeil 
was regarded as supreme, with authority to make or unmake any law, the concepts of legal positivism and parliamentary sovereignty were mutually reinforcing. It is therefore no coincidence that Dicey's classic exposition of the doctrine of parliamentary sovereignty was written in the late nineteenth century when legal positivism dominated British jurisprudential thought. ${ }^{74}$

The doctrine of parliamentary sovereignty is clearly one of the principles of the British Constitution which the courts incorporated into the Canadian Constitution by means of the preamble to the Constitution Act, $1867 .{ }^{75}$ But of course the doctrine has never exactly fit the Canadian context. As Canada was originally part of the British Empire, Canadian legislatures were subject to the overriding supremacy of the British Parliament, as expressly provided by the Colonial Laws Validity Act of $1865 .{ }^{76}$ Moreover,

74. Dicey, supra note 69 (1st ed., 1885). Dicey, in his discussion of the connection between the doctrine of parliamentary sovereignty and Austin's theory of sovereignty, suggested that Austin's theory was probably influenced more by the position of Parliament than vice versa: ibid. at 71-76. Note that Dicey's views on the omnipotence of Parliament have been criticized by some constitutional theorists who take a more restrictive approach: see especially Sir W. Ivor Jennings, The Law and the Constitution, 5th ed. (London: University of London Press, 1959) at 137-179; Heuston, supra note 67 at 1-7. The modern debate on the doctrine revolves mainly around the issue of whether one Parliament can bind its successors, in particular with "manner and form" legislation: see e.g. Geoffrey Marshall, Constitutional Theory (Oxford: Clarendon Press, 1971) at 35-57; F.M. Brookfield, "Parliamentary Supremacy and Constitutional Entrenchment: A Jurisprudential Approach" (1984) 5 Otago L. Rev. 603; R. Elliot, "Rethinking Manner and Form: From Parliamentary Sovereignty to Constitutional Values" (1991) 29 Osgoode Hall L.J. 215.

75. The courts would likely have done this even without the invitation contained in the preamble, as they applied the doctrine to pre-Confederation legislation of the Canadian colonies as well: see e.g. Labrador Company v. The Queen, [1893] A.C. 104 at 123, where the Privy Council decided that a provision of an 1856 Act of the legislature of the Province of Canada could not be disregarded by the courts "[e]ven if it could be proved that the legislature was deceived. . . If a mistake has been made, the legislature alone can correct it."

76. (U.K.) $28 \& 29$ Vict., c. 63. As Brian Slattery has convincingly shown in his article, "The Independence of Canada" (1983) 5 Supreme Court L.R. 369 at 384 385 , the $A c t$ was merely declaratory in this respect, as otherwise the authority to make it apply to the Crown's overseas dominions would have been lacking. Its application to Canada, along with the general authority of the British Parliament 
the Crown in Britain could veto Canadian legislation through the exercise of the powers of reservation and disallowance in ss. 55 to 57 of the Constitution Act, 1867.7 The federal system itself imposed an additional limitation on parliamentary sovereignty by restricting the competence of the provincial legislatures to certain subject matters, and by excluding matters within exclusive provincial jurisdiction from federal competence. ${ }^{78}$ Some scholars see further restrictions on the applicability of the doctrine arising from the fact that, unlike Britain, Canada has an. entrenched, written Constitution. ${ }^{79}$ These restrictions are even more extensive today, given the limitations that the Charter of Rights and Freedoms places on both federal and provincial legislative competence. ${ }^{80}$

I do not intend to enter into the debate over whether the courts should have uncritically applied the doctrine of parliamentary sovereignty in Canada. The fact is they bave applied it, and as a result it has become a guiding principle in Canadian constitutional

to legislate effectively for Canada apart from the British North America Acts (now the Constitution Acts), ended with the enactment of the Statute of Westminster, 1931 (U.K.), 22 Geo. V, c. 4. See ibid. at 390-399; and Hogg, supra note 2 at 47-51.

77. Supra note 65 . Although these provisions have never been expressly repealed, they have not been used since 1878; moreover, at the Imperial Conference of 1930 which preceeded the enactment of the Statute of Westminster, it was agreed that they would no longer be used: see Hogg, supra note 2 at 46, n. 4.

78. See Robert Yalden, "Liberalism and Canadian Constitutional Law: Tensions in an Evolving Vision of Liberty" (1988) 47 U.T. Fac. L. Rev. 132 at 140; and Hogg, supra note 2 at 302-303.

79. See Noel Lyon, "The Central Fallacy of Canadian Constitutional Law" (1976) $22 \mathrm{McGill}$ L.J. 40; and Elliot, supra note 74 at 235-236.

80. See: Anne F. Bayefsky, "The Judicial Function under the Canadian Charter of Rights and Freedoms" (1987) 32 McGill L.J. 791 at 810-811; Madam Justice Bertha Wilson, "The Making of a Constitution: Approaches to Judicial Interpretation" [1988] Public Law 370 at 371. Compare Hogg, supra note 2 at 305: "The [s. 33] override provision... preserves parliamentary supremacy over much of the Charter." On the same page, Hogg even suggests that parliamentary sovereignty in Canada has been perfected by the Constitution Act, 1982, as power to amend the Constitution can now be exercised by the Canadian Parliament and the requisite number of provincial legislatures: "If one thinks of the Part $\mathrm{V}$ amending procedures as a third legislative process, then it is now literaly true that legislative power in Canada is exhaustively distributed among Canadian institutions." 
law. ${ }^{81}$ Within their respective areas of jurisdiction, the Canadian Parliament and the provincial legislatures have been said to be supreme, with the same authority as the British Parliament. ${ }^{82}$ Moreover, all legislative and executive powers exercisable in Canada have been thought to be distributed between the federal and provincial governments. ${ }^{83}$ In the words of Earl Loreburn, "whatever belongs to self-government in Canada belongs either to the Dominion or to the provinces, within the limits of the British North America Act. ${ }^{18}$ By implication, the Constitution left no residual powers of self-government to the Aboriginal peoples. ${ }^{85}$ As a result, any governmental authority actually exercised by them has been due either to sufferance, or to delegation under the federal Indian $A c t^{86}$ or other legislation. ${ }^{87}$

81. On occasion, some members of the Supreme Court of Canada have attempted to limit the application of the doctrine of parliamentary sovereignty in the interest of fundamental human rights. See e.g.: Reference Re Alberta Statutes, [1938] S.C.R. 100; Saumur v. Quebec (City of), [1953] 2 S.C.R. 299; Switzman v. Elbling and Quebec (A.G.), [1957] S.C.R. 285. However, these "implied bill of rights" cases failed to overturn the dominant view that it is not up to the courts to question the wisdom of legislation. When the Court was confronted with a real Bill of Rights after 1960, it briefly took on its new role of assessing legislation in $R$. v. Drybones, [1970] S.C.R. 282, and then quickly retreated to a more traditional position of deference. See: Lyon, supra note 79 at 50-58; Walter Surma Tarnopolsky, The Canadian Bill of Rights, 2d ed. (Toronto: McClelland and Stewart, 1975) especially at 294-304; Berend Hovius and Robert Martin, "The Canadian Charter of Rights and Freedoms in the Supreme Court of Canada" (1983) 61 Can. Bar Rev. 354, especially at 374-376.

82. See: Hodge v. R. (1883), 9 App. Cas. 117 at 132 (P.C.); Liquidators of the Maritime Bank of Canada v. New Brunswick (Receiver General), [1892] A.C. 437 at 442 (P.C.). For critical comment see Lyon, supra note 79 at 43-44.

83. See: Bank of Toronto v. Lambe (1887), 12 App. Cas. 575 at 587 (J.C.P.C.); Union Colliery Co. v. Bryden, [1899] A.C. 580 (P.C.); Murphy v. C.P.R., [1958] S.C.R. 626 at 643; Jones v. New Brunswick (A.G.), [1975] 2 S.C.R. 182 at 195.

84. Ontario (A.G.) v. Canada (A.G.), [1912] A.C. 571 at 584 (P.C.).

85. For discussion, see Ryder, supra note 23 at 310-316.

86. R.S.C. 1985, c. I-5. See Bear Island, supra note 16 at 78 and 80; and Logan, supra note 16.

87. See e.g. James Bay and Northern Quebec Native Claims Settlement Act, S.C. 1976-77, c. 32; Loi approuvant la Convention de la Baie James et du Nord québécois, L.R.Q. 1977 c. C-67; Sechelt Indian Band Self-Government Act, S.C. 1986, c. 27; Sechelt Indian Government District Enabling Act, S.B.C. 1987, c. 16. 
The enactment of the Constitution Act, 1982 provided an opportunity to end the colonialism inherent in the view that legislative powers were exhaustively distributed in 1867 between the federal and provincial governments. The Charter, and the express provision in s. 52(1) that the "Constitution of Canada is the supreme law of Canada," made a reassessment of the doctrine of parliamentary sovereignty imperative, as certain matters were clearly placed beyond the competence of either order of government. ${ }^{88}$ Where the Aboriginal peoples are concerned, s. 35(1) demanded a reassessment of this kind by recognizing and affirming their Aboriginal and treaty rights. The section could have been interpreted as placing those rights outside federal and provincial jurisdiction. This would have created a jurisdictional vacuum which could have been filled by Aboriginal governments, terminating the constitutional colonialism under which the Aboriginal peoples have suffered since 1867.

To understand further why the Supreme Court did not interpret s. 35(1) this way in Sparrow, attention must be given to another fundamental principle of the British Constitution, namely the rule of law. ${ }^{89}$ This rule was implicitly included in the Canadian Constitution by the preamble to the Constitution Act, $1867 . .^{90}$ Its constitutional status has since been affirmed by the preamble to the Constitution Act, 1982, which states that "Canada is founded on principles that recognize the supremacy of God and the rule of law." 11 In addition, the Supreme Court of Canada has said that

88. Note that this was the case to a lesser extent even before the $1982 \mathrm{Act}$, as certain matters, such as some official uses of the French and English languages in Quebec, Manitoba, and at the federal level, were al ready constitutionally protected: see Ryder, supra note 23 at 310, n. 4, and discussion of Reference Re Manitoba Language Rights, [1985] 1 S.C.R. 721 [hereinafter Manitoba Language Rights], in text accompanying infra notes 96-108.

89. On this rule, see generally Dicey, supra note 69, especially at 187-203; Jennings, supra note 74 at $42-62$ and 305-317; Heuston, supra note 67 at 32-57; Wade and Bradley, supra note 67 at 91-104; and Allan C. Hutchinson and Patrick Monahan, eds., The Rule of Law: Ideal or Ideology (Toronto: Carswell, 1987).

90. By the words "with a Constitution similar in principle to that of the United Kingdom:" see Manitoba Language Rights, supra note 88 at 750.

91. Ibid.

K. McNeil 
the rule is "clearly implicit in the very nature of a Constitution," even if not specifically set out. ${ }^{92}$

The rule of law has two main aspects. ${ }^{93}$ First, it entails that, to govern the relationships and dealings of people in society, a generally accepted and enforceable body of law exist. This body of law provides stability and order, and guides the members of the society in their interactions with one another. Second, the rule of law requires that everyone, including government officials, be subject to the accepted body of law, and act in accordance with it. In other words, no one is above the law. This protects the members of the society from arbitrary acts by persons in authority, ensuring that they do not interfer with rights and freedoms without legal justification. ${ }^{94}$

It is the first aspect of the rule of law that is particularly relevant to the Supreme Court's interpretation of s. 35(1) in Sparrow: Its primacy in Canadian constitutional law is revealed by the Court's earlier unanimous decision in Reference Re Manitoba Language Rights. ${ }^{95}$ This decision considered the effect of an earlier ruling that an 1890 Manitoba statute, ${ }^{96}$ purporting to revoke the official status of the French language in the province, was unconstitutional because it violated s. 23 of the Manitoba Act,

92. Ibid. at 750-751.

93. Ibid. at 748-750. Note that in my discussion I am reversing the order of the Supreme Court's treatment of these aspects in the Manitoba Language Rights case.

94. See: Entick v. Carrington (1765), 19 How. S.T. 1030 (C.P.); Roncarelli v. Duplessis, [1959] S.C.R. 121. For an insightful discussion of this aspect of the rule, see Allan, supra note 47 at 111-143.

95. Supra note 88. For discussion, see: Margaret A. Banks, "Defining 'Constitution of the province' - The Crux of the Manitoba Language Controversy" (1986) 31 McGill L.J. 466; S.J. Whitley, "The Manitoba Language Reference: Judicial Consideration of 'Language Charged with Meaning'" (1986) 15 Man. L.J. 295; Dale Gibson and Kristin Lercher, "Reliance on Unconstitutional Laws: The Saving Doctrines and Other Protections" (1986) 15 Man. L.J. 305; Denise Réaume, "Language, Rights, Remedies, and the Rule of Law" (1988) 1 Can. J. Law \& Jur. 35

96. An Act to Provide that the English Language shall be the Official Language of the Province of Manitoba, S.M. 1890, c. 14. 
$1870 .{ }^{97}$ The Supreme Court decided that, because the 1890 statute was unconstitutional, every Manitoba enactment in English only was "invalid and of no force or effect." ${ }^{\text {" }}$ As almost all the enactments since 1890 fell into this category, the Court was then faced with the repercussions of invalidating most of the statute law in Manitoba. Unless some solution could be found, the Court realized that "a legal vacuum [would] be created with consequent legal chaos in the Province." More specifically, "the positive legal order which [had] purportedly regulated the affairs of the citizens of Manitoba since 1890 [would] be destroyed and the rights, obligations and other effects arising under these laws [would] be invalid and unenforceable." 100

The Court's solution to this problem was to invoke the rule of law as a fundamental constitutional principle to maintain the application of the invalid statutes until they could be translated into French, and re-enacted in both official languages. In this way, the Court was able "to recognize the unconstitutionality of Manitoba's unilingual laws and the Legislature's duty to comply with the 'supreme law' of this country, while avoiding a legal vacuum in Manitoba and ensuring the continuity of the rule of law."101

The Court arrived at this solution by giving paramountcy to the principle of the rule of law, one of the "unwritten postulates which form the very foundation of the Constitution of Canada." ${ }^{102}$ In doing so, the judges gave more weight to implied legislative intent than to strict textual construction:

This Court cannot take a narrow and literal approach to constitutional interpretation. The jurisprudence of the Court evidences a willingness to

97. S.C. 1870 , c. 3, affirmed by the Constitution Act, 1871 (previously the British North America Act, 34 \& 35 Vict., c. 28 (U.K.)). Manitoba (A.G.) v. Forest, [1979] 2 S.C.R. 1032, decided that the 1890 statute was in conflict with s. 23, and therefore invalid.

98. Supra note 88 at 747.

99. Ibid. at 747.

100. Ibid. at 749 .

101. Ibid. at 753 .

102. Ibid. at 752 . 
supplement textual analysis with historical, contextual and purposive interpretation in order to ascertain the intent of the makers of our Constitution. ${ }^{103}$

In the Court's view, "[t]he founders of this nation must have intended, as one of the basic principles of nation building, that Canada be a society of legal order and normative structure: one governed by rule of law." 104 The Court would not permit this principle to be violated by allowing strict application of the Constitution to create chaos and disorder. ${ }^{105}$ More specifically,

[t]he Constitution will not suffer a province without laws. Thus the Constitution requires that temporary validity and force and effect be given to the current Acts of the Manitoba Legislature. ... It is only in this way that legal chaos can be avoided and the rule of law preserved. ${ }^{106}$

Avoiding legal chaos through the application of the rule of law is therefore a paramount constitutional value which takes precedence over the written terms of the Constitution. ${ }^{107}$

In my view, the Supreme Court's approach to the language rights issue in Manitoba may help to explain why the Court was unwilling to interpret s. 35(1) of the Constitution Act, 1982 as providing Aboriginal and treaty rights with absolute protection against federal laws. Unless there are Aboriginal laws ${ }^{108}$ governing Aboriginal and treaty rights throughout Canada, this inter-pretation would have created a partial legal vacuum, which was the very thing the Court took such pains to avoid in Manitoba. In the context of Sparrow, the legal vacuum would have encompassed Aboriginal fishing for food and ceremonial purposes, which would have been completely unregulated in the absence of

103. Ibid. at 751 .

104. Ibid.

105. Ibid. at 766 .

106. Ibid. at 767.

107. By maintaining the validity of Manitoba's statutes until they could be translated and re-enacted, the Court temporarily overrode the explicit terms of s. 52(1) of the Constitution Act, 1982 that "any law that is inconsistent with the provisions of the Constitution is, to the extent of the inconsistency, of no force or effect."

108. By "Aboriginal laws" I mean the laws of the Aboriginal peoples themselves, whether derived from custom, 'legislative' enactment, or some other source. 
Aboriginal laws governing this activity. The Supreme Court found this possibility unacceptable, as it could lead to depletion of the very resource which makes the Aboriginal right to fish meaningful. So, in the Court's view, federal legislative authority over Aboriginal fishing had to continue in the interest of conservation, subject to the justificatory test we have already discussed.

But Aboriginal and treaty rights cover much more than fishing for food and ceremonial purposes. In many cases, they probably include fishing for commercial purposes as well. ${ }^{109}$ They generally include hunting and trapping, which can also be commercial. ${ }^{110}$ Aboriginal rights encompass the use of other natural products of lands and waters covered by Aboriginal title, as well as an interest in the land itself." They may also include any other uses to which Aboriginal lands can be put, such as agriculture and commercial development. ${ }^{112}$ Aboriginal and treaty rights probably both extend to the maintenance of Aboriginal customs and traditions, including the use of Aboriginal languages, ${ }^{113}$ and the practice of Aboriginal spirituality. ${ }^{114}$ In

109. See: Agawa, supra note 17; R. v. Vanderpeet, [1991] 3 C.N.L.R. 161 (B.C.S.C.).

110. See e.g. Horseman v. R., [1990] 1 S.C.R. 901 [hereinafter Horseman], where it was held that a treaty right to hunt commercially had been taken away in Alberta by the Natural Resources Transfer Agreement, 1930.

111. The nature of this interest has never been clearly determined by Canadian courts: see discussion in Slattery, "Understanding Aboriginal Rights," supra note 2; Kent McNeil, Common Law Aboriginal Title (Oxford: Clarendon Press, 1989) at 267-290, and "The Temagami Indian Land Claim: Loosening the Judicial Straitjacket" in Matt Bray and Ashley Thomson, eds., Temagami: A Debate on Wilderness (Toronto: Dundern Press, 1990) 185. Nor was the matter clarified by Delgamuukw, supra note 16, a decision which has been severely criticized. See: Frank Cassidy, ed., Aboriginal Title in British Columbia: Delgamuukw v. The Queen (Lantzville, B.C.: Oolichan Books, 1992). Compare Mabo v. Queensland (1992), 175 C.L.R. 1, on Aboriginal title in Australia.

112. See Slattery, "Understanding Aboriginal Rights," supra note 2 at 746-748.

113. See Brian Slattery, "Aboriginal Language Rights" in David Schneiderman, ed., Language and the State: The Law and Politics of Identity (Cowansville, Que.: Les Editions Yvone Blais, 1991) at 369-374.

114. See Jack and Charlie, supra note 23.

K. McNeil 
short, Aboriginal and treaty rights arguably cover all aspects of Aboriginal life. To the extent that those rights were not extinguished prior to the enactment of the Constitution Act, 1982, they are recognized and affirmed by s. 35(1).

The Supreme Court is obviously aware of the uncertain and potentially open-ended nature of Aboriginal and treaty rights. ${ }^{115}$ In deciding Sparrow, it knew that the general interpretation it placed on s. 35(1) would apply not only to the Aboriginal right of the Musqueam Nation to fish for food and ceremonial purposes, but to every Aboriginal and treaty right of all the Aboriginal peoples across Canada. If the Court had decided that those rights are beyond the regulatory power of both the federal and provincial legislatures, that could have created a legal vacuum which might have been even more damaging to public order and the stability of Canadian society, from the perspective of the judges, than a declaration that almost all the provincial statutes in Manitoba were void. The rule of law, as the Court understood and articulated that concept in the Manitoba Language Rights decision, would have been violated. As in the case of Manitoba, the Court was therefore willing to bend the actual terms of the Constitution to avoid that result. Where the unilingual Manitoba statutes were concerned, it did this by maintaining their force until they could be translated and re-enacted in both official languages. Where Aboriginal and treaty rights were concerned, it accomplished the same thing by maintaining federal jurisdiction over them, subject to the justificatory test which the Court created. ${ }^{116}$

However, relying on the rule of law to explain this continuation of federal jurisdiction is problematic because it seems to assume that the Aboriginal peoples do not have adequate laws of their own to govern the exercise of their rights. But the absence of such laws should not be assumed, particularly in light of modern

115. The Court itself has avoided giving a clear definition of Aboriginal title, which is just one element of Aboriginal rights: see Guerin, supra note 43, and discussion in McNeil, Common Law Aboriginal Title, supra note 111 at 284-289.

116. While this objective was not articulated in the Sparrow decision, the Manitoba Language Rights case was referred to, in suppport of the Supreme Court's purposive interpretation of s. 35(1): Sparrow, supra note 12 at 1106. 
anthropological evidence that all societies have rules governing interactions among their members. ${ }^{117}$ Of course those rules vary from one society to another, and do not necessarily cover the same aspects of human behavior. Moreover, the mechanisms for enforcement of the rules can be very different. ${ }^{118}$ However, these are not reasons for denying these rules the status of laws. The assumption that Aboriginal societies do not have laws governing activities such as fishing should not be made without a factual basis. Furthermore, one should not expect Aboriginal laws necessarily to be enacted by legislative bodies, or to be written down. Those expectations would be ethnocentric and inappropriate, as they would involve imposing Euro-Canadian standards on Aboriginal societies. ${ }^{119}$

The Supreme Court may not have assumed in Sparrow that the Musqueam Nation had no laws of its own governing fishing by its members. But it did seem to think that any laws the Musqueam may have had would be inadequate to regulate their fishing in the interest of conservation because, as we have seen, the Court said that s. 35(1) did not provide them with "immunity from government regulation in a society that, in the twentieth century, is increasingly more complex, interdependent and sophisticated, and where exhaustible resources need protection and management." ${ }^{20}$ The word "government" in this passage obviously means the kind of government the judges are accustomed to, in this context the federal government. The Court did not envisage that Aboriginal governments would be capable of ensuring that finite resources are

117. See Michael Asch, "Errors in Delgamuukw: An Anthropolgical Perspective" in Cassidy, ed., supra note 112 at 221-43, especially 224-225.

118. See e.g.: Michael Coyle, "Traditional Indian Justice in Ontario: A Role for the Present?" (1986) 24 Osgoode Hall L.J. 605; A.C. Hamilton and C.M. Sinclair, Report of the Aboriginal Justice Inquiry of Manitoba, Vol. 1: The Justice System and Aboriginal People (Winnipeg: Province of Manitoba, 1991) at 22-29; Michael Jackson, "In Search of the Pathways to Justice: Alternative Dispute Resolution in Aboriginal Communities" (1992) Special Ed. U.B.C. L. Rev. 147.

119. See Michael Asch and Catherine Bell, "Definition and Interpretation of Fact in Canadian Aboriginal Title Litigation: A Comment on Delgamuukw" (February 1993) [unpublished].

120. Supra note 12 at 1110 .

K. MeNeil 
not depleted by Aboriginal use. The colonial vision of the Canadian Constitution, based on parliamentary sovereignty and exhaustive distribution of powers between the federal and provincial governments, was still influencing the judges. Moreover, it is apparent that they feared that, if they interpreted s. 35(1) as absolutely protecting Aboriginal and treaty rights, this would create a legal vacuum, which would violate the rule of law as the Court understood it. Just as "government" does not include Aboriginal government, "law" does not include Aboriginal law. I think that this judicial mindset is behind the Court's conclusion that Aboriginal rights can still be infringed by federal legislation, as nothing in the actual words of s. 35(1) leads to this result.

Support for my appraisal of the Court's approach to s. 35(1) in Sparrow can be found by comparing it with the way the Court assessed another constitutional provision guaranteeing Aboriginal and treaty rights, namely a provision in the Natural Resources Transfer Agreements. ${ }^{121}$ These agreements transferred most public lands and resources in Manitoba, Saskatchewan, and Alberta to the Crown in right of those provinces in 1930, placing them in a position equal to that of the other Canadian provinces, which had retained their lands and resources when they entered Confederation. ${ }^{122}$ In order to provide limited protection to Aboriginal and treaty rights to hunt, trap, and fish for food, the following provision, which I refer to as the game laws paragraph, was included in the agreements:

In order to secure to the Indians of the Province the continuance of the supply of game and fish for their support and subsistence, Canada agrees that the laws respecting game in force in the Province from time to time shall apply to the Indians within the boundaries thereof, provided, however, that the said Indians shall have the right, which the Province hereby assures to them, of hunting, trapping and fishing game and fish for food at all seasons of the year on all

121. These agreements were implemented by federal and provincial legislation in the three prairie provinces, as well as by Imperial legislation. The Imperial legislation, the British North America Act, 1930, $20 \& 21$ Geo. V, c. 26 (U.K.), which is now the Constitution $A c t, 1930$ gave these agreements constitutional status, as the Schedule to the Constitution Act, 1982 confirms.

122. This is due to s. 109 of the Constitution Act, 1867. 
unoccupied Crown lands and on any other lands to which the said Indians may have a right of access. ${ }^{123}$

The game laws paragraph has been interpreted and applied in numerous Supreme Court of Canada decisions. ${ }^{124}$ Those decisions have held that, so long as the Indians in question are hunting, trapping, or fishing for food on the lands referred to, they are not subject to provincial game laws. ${ }^{125}$ The Court has always treated the constitutional protection provided by the paragraph as an absolute guarantee, without concerning itself with the impact that might have on conservation. ${ }^{126}$ In light of the

123. Constitution Act, 1930, Schedule (1), Manitoba, Para. 13; Schedule (2), Alberta, Para. 12; Schedule (3), Saskatchewan, Para. 12.

124. See e.g.: Prince and Myron v. R., [1964] S.C.R. 81 [hereinafter Prince]; Cardinal v. Alberta (A.G.), [1974] S.C.R. 695; Myran v. R., [1976] 2 S.C.R. 137; Frank v. R., [1978] 1 S.C.R. 95; McKinney v. Canada, [1980] 1 S.C.R. 401; R. v. Mousseau, [1980] 2 S.C.R. 89; R. v. Sutherland, [1980] 2 S.C.R. 451 [hereinafter Sutherland]; Moosebunter v. R. (1978), 43 C.C.C. (2d) 15 (Sask. C.A.), rev'd on other grounds [1981] 1 S.C.R. 282 [hereinafter Moosebunter]; R. v. Horse, [1988] 1 S.C.R. 187; Horseman, supra note 110.

125. For detailed discussion, see McNeil, supra note 23 at 20-45.

126. In Sutherland, supra note 124, the Supreme Court applied the Saskatchewan Court of Appeal decision in R. v. Strongquill, (1953) 8 W.W.R. (N.S.) 247 [hereinafter Strongquill], where Gordon J.A. said at 260, in the context of the game laws paragraph, that "Indians should be preserved before moose." Dehumanizing as that statement may be, it nonetheless reveals that the Court of Appeal thought that the Indian right to hunt for food took precedence over conservation. Also, in Prince, supra note 124, the Supreme Court disregarded the conservation concerns expressed by the majority in the Manitoba Court of Appeal, (1962) 40 W.W.R. 234 , and decided that provincial game laws restricting methods of hunting do not apply to Indians who are hunting for food. In so doing, the Court agreed with the reasons of Freedman J.A., who wrote in his dissenting judgment at 243:

That indiscriminate resort to unsportsmanlike methods [in this case, use of night lights] of hunting and fishing would be prejudicial to the supply of game and fish is no doubt true. The answer, however, lies in the education of the Indian so he will appreciate that what is in the best interests of the citizenry of Manitoba is also in his own best interests. The answer does not consist in construing the section contrary to what appears to me to be its plain and dominant purpose.

(The lack of appreciation in this passage of Aboriginal values of conservation is worth noting.) Compare Horseman, supra note 110, where Cory J., in his majority judgment, did use conservation as a reason for concluding that the paragraph does 
Sparrow decision, this may appear surprising. However, I think the explanation for this apparent discrepancy lies in the fact that the courts have found other means to avoid whatever negative impact the game laws paragraph might have on conservation. First, courts have decided that Crown lands which have been set aside by a province bona fide as game preserves are occupied, and therefore are not available for Indian hunting, trapping, or fishing, unless there is a right of accesss for those purposes. ${ }^{127}$ However, game preserves might not be adequate for conservation in some instances, particularly if a species, such as the whooping crane, is in danger of extinction. Without explicitly addressing this issue, the Supreme Court has nonetheless dealt with it by deciding that the game laws paragraph does not protect Indian hunting, trapping, and fishing against federal legislation. ${ }^{128}$ As Parliament probably has broad jurisdiction to regulate these Aboriginal activities under s. 91(24) of the Constitution Act, 1867, ${ }^{129}$ this means that federal legislation can always be enacted if necessary for conservation. ${ }^{130}$ In other words, the Court interpreted the game laws paragraph in a way that maintained parliamentary sover-

not provide constitutional protection for commercial hunting. However, Cory J. based that conclusion on his interpretation of the words "for food" in the paragraph. In no case has the Court said that conservation needs would override the protection which the paragraph provides for Indian subsistence hunting.

127. R. v. Smith, [1935] 2 W.W.R. 433 (Sask. C.A.); Strongquill, supra note 126; R. v. Kootenay and Two Youngmen (1978), 6 Alta. L.R. (2d) 220 (Alta. Prov. Ct.), aff'd (1979), 10 Alta. L.R. (2d) 15 (Alta. D.C.); Moosebunter, supra note 124; $R$. v. Ross (1985), 47 Sask. R. 317 (Sask. C.A.); R. v. Wolverine and Bernard (1989), 74 Sask. R. 224 (Sask. C.A.): see discussion in McNeil, supra note 23 at 34-36. However, provincial legislation which designates certain lands, including wildlife management areas, as occupied for the purposes of the game laws paragraph is constitutionally invalid: Sutherland, supra note 124.

128. See Daniels, supra note 21; Elk v. R., [1980] 2 S.C.R. 166.

129. See McNeil, supra note 23 at 12-17. Of course this is now subject to s. 35(1) of the Constitution Act, 1982, and the justificatory test in Sparrow.

130. See R. v. Wesley, [1932] 2 W.W.R. 337 (Alta. C.A.) at 341, where Lunney J.A., said that "[i]f it should be necessary or desirable to curtail the hunting rights of the Indian, provision has been made to that effect" (by s. 69 of the Indian Act, R.S.C. 1927, c. 28, which empowered the federal Minister of the Interior to declare that the game laws in any of the prairie provinces should apply to the Indians therein). 
eignty, and its own vision of the rule of law, over Aboriginal hunting, trapping, and fishing in the prairie provinces. ${ }^{131}$

Nor has the Supreme Court given conservation priority over Aboriginal hunting rights when considering the effect of $s .88$ of the Indian $A c t^{132}$ which, with certain exceptions, subjects Indians to provincial laws of general application. ${ }^{133}$ On the contrary, in his unanimous judgment in Kruger, Dickson J. said that if it could be shown that

the Province has acted in such a way as to oppose conservation and Indian claims to the detriment of the latter - to 'preserve moose before Indians' in the words of Gordon J.A. in $R$. v. Strongquill - it might very well be concluded that the effect of the legislation is to cross the line demarking laws of general application from other enactments. ${ }^{134}$

Just before making this obiter statement, Dickson J. remarked:

Game conservation laws have as their policy the maintenance of wildlife resources. It might be argued that without some conservation measures the ability of Indians or others to hunt for food would become a moot issue in consequence of the destruction of the resource. ${ }^{135}$

While Dickson J. appears to want to have it both ways in these contrasting passages, the dilemma is resolved by a statement he made in the preceding paragraph:

131. The Court did not give this explanation of its interpretation of the paragraph in either of the decisions referred to, supra note 128 . Instead, it relied mainly on textual analysis. The fact remains that the result of those decisions is consistent with preserving parliamentary sovereignty and the view of the rule of law to which the Court gave precedence in the Manitoba Language Rights case.

132. Supra note 86.

133. The constitutionality of this provision is now open to question, due to s. 35(1) of the Constitution Act, 1982: see Slattery, "First Nations and the Constitution," supra note 2 at 285-286.

134. Kruger, supra note 23 at 112.

135. Ibid., quoted in Sparrow, supra note 12 at 1114.

K. McNeil 
However abundant the right of Indians to hunt and to fish, there can be no doubt that such right is subject to regulation and curtailment by the appropriate legislative authority. ${ }^{136}$

In situations where a province was constitutionally prevented from "oppos[ing] conservation and Indian claims to the detriment of the latter," the "appropriate legislative authority" Dickson J. had in mind was obviously the Parliament of Canada. So as in the case of the Natural Resources Transfer Agreements, parliamentary sovereignty in the interest of conservation is maintained over Indian hunting and fishing. ${ }^{137}$

Kruger and Manuel should be compared with the judgments in Jack v. The Queen, ${ }^{138}$ decided by the Supreme Court two years later. The appellants in that case, who were status Indians under the Indian $A c t,{ }^{139}$ argued that provisions of the federal Fisheries $A c t^{140}$ prohibiting salmon fishing in certain rivers during specified periods did not apply to them when they were fishing for food. In their view, article 13 of the Terms of Union of British Columbia with Canada protected their Aboriginal food fishery from federal legislation, as Canada was constitutionally obliged by that article to continue a policy "as liberal as that hitherto pursued by the British Columbia Government." ${ }^{141}$ Chief Justice Laskin dismissed this argument in the following terms:

I see nothing in art. 13 that could possibly operate as an inhibition on federal legislative power in relation to fisheries. Whatever policy may have existed in preConfederation British Columbia of toleration of Indians fishing for food ... there does not appear to have been any basis in law to ordain the policy. Nor can any legal sanction for such Indian fishing rights be spelled out of art. 13. ${ }^{142}$

136. Ibid., note 23 at 111-112 (of course this was prior to the enactment of s. 35(1) of the Constitution Act, 1982).

137. See also George, supra note 21.

138. [1980] 1 S.C.R. 294 [hereinafter Jack].

139. R.S.C. 1970 , c. $1-6$.

140. Supra note 19.

141. British Columbia Terms of Union, R.S.C. 1985, App. II, No. 10, at 7.

142. Jack, supra note 138 at 299. 
Regarding a point made by the respondent about conservation, Laskin C.J. observed that the appellants' counsel "conceded that the prohibitory order, if made for conservation purposes, would govern any Indian fishing rights. ${ }^{143} \mathrm{He}$ said he was inclined to the view that the prohibition served a conservation purpose, from which he concluded: "Hence, even if the fishing rights claimed were established, they would have been properly subordinated to conservation of the fisheries in the particular rivers." 144

Dickson J., in a separate judgment concurring in the result, disagreed with the majority view that article 13 did not place any restrictions on Canada's authority to regulate the Indian fishery. In his view, "[t]he reference to 'policy' in art. 13 establishes a limitation upon the federal legislative power in relation to the Indian fishery and sets up a standard against which that federal legislation is to be tested." 145 However, Dickson J. said the words "a policy as liberal" allow for flexibility, and require the Court

to balance the pre-Confederation policy with the current measures. In assessing the liberality of the post-Confederation policy, it is necessary to take into account both the emergence of conservation as a limitation by reason of declining fish stocks and the development of a commercial and sports fishery after $1871 . .^{146}$

Dickson J. would have given Indian food fishing, and to a lesser extent Indian commercial fishing, priority over non-Indian commercial and sports fishing. However, for him conservation came first:

[A]ny limitation upon Indian fishing that is established for a valid conservation purpose overrides the protection afforded the Indian fishery by art. 13, just as such conservation measures override other taking of fish. ${ }^{147}$

143. Ibid. at 300 .

144. Ibid.

145. Ibid. at 312 .

146. Ibid. at 312-313.

147. Ibid. at 313. Dickson J.'s judgment in Jack obviously had a strong influence on the decision which he and La Forest J. delivered in Sparrow: see supra note 12 at 1115-1116. 
On the facts, he found that the closure of certain rivers to salmon fishing "was reasonable and necessary for the purpose of conservation and [did] not offend against the priority assured to the Indian fishery by reason of art. 13 of the Terms of Union. ${ }^{148}$

Chief Justice Laskin and Dickson J. therefore agreed that, if article 13 placed constitutional restrictions on federal legislative powers relating to Indian fishing, federal regulations for valid conservation purposes would nonetheless override the protection which article 13 provided. As in Sparrow, the Supreme Court was therefore unwilling to allow a constitutional provision to impinge on parliamentary sovereignty where the valid legislative objective of conservation was concerned.

Our brief examination of the Natural Resources Transfer Agreements and s. 88 of the Indian Act revealed that the Supreme Court did not take conservation into account when constitutional restrictions on provincial legislative powers over Aboriginal hunting and fishing were involved. However, when constitutional restrictions on federal legislative powers were suggested in the context of the British Columbia Terms of Union, the Court was willing to use conservation to limit the scope of the alleged restrictions. In my view, the reason courts treat these situations differently is that, if necessary for conservation, the federal government could enact legislation to regulate Aboriginal hunting and fishing which the provinces were unable to regulate, ${ }^{149}$ but conversely the provinces could not conversely legislate to replace federal laws that were found unconstitutional in the same context. ${ }^{150}$ In each of these situations, the Supreme Court has maintained its own vision of parliamentary sovereignty and the rule of law by preserving federal legislative power. Subject to the justificatory test, it did the same thing in Sparrow, despite the fact

148. Jack, supra note 138 at 315.

149. As we have seen, Parliament's jurisdiction over these activities probably comes from s. 91(24) of the Constitution Act, 1867: see supra note 129 and text.

150. The fact that the Supreme Court differentiated between provincial and federal powers in this way where earlier constitutional protections of Aboriginal rights were concerned supports the argument that, in the context of s. 35(1), provincial laws which infringe Aboriginal or treaty rights cannot be justified by the Sparrow test: see supra note 23. 
that s. 35(1) provided the Court with an opportunity to envisage a protected constitutional space within which Aboriginal governments could flourish and grow.

\section{A Constitutional Space for Self-Government}

Our discussion so far suggests that, despite s. 35(1), the Supreme Court of Canada is still operating within a colonial paradigm of constitutional law insofar as the rights of the Aboriginal peoples are concerned. In Sparrow, the Court reaffirmed the standard colonial view that "there was from the outset never any doubt that sovereignty and legislative power, and indeed the underlying title, to [Aboriginal] lands vested in the Crown. ${ }^{151}$ Moreover, the colonial paradigm does not envisage an alternative to this denial of Aboriginal sovereignty, as the complementary principles of parliamentary sovereignty and the rule of (Euro-Canadian) law exclude Aboriginal governments and laws from their legitimate place within the Canadian Constitution.

By proposing recognition of the inherent Aboriginal right of self-government in the Constitution, the Charlottetown Accord might have sounded the death knoll for the colonial paradigm in Canadian constitutional thought. However, with the defeat of the Accord by the electorate, that opportunity to recognize the right explicitly has been lost, at least for the time being. So, within the context of the Canadian Constitution, the Aboriginal peoples are left with s. 35(1), as interpreted by the Supreme Court in Sparrow. There may nonetheless be a way to use that decision for the promotion of self-government. The key is to meet the Court's unarticulated, but evident, concern that a jurisdictional and legal vacuum would result if federal authority over Aboriginal and treaty rights was excluded by s. 35(1).

To do this, one first needs to redefine the British conceptions of parliamentary sovereignty and the rule of law in ways that are

151. Sparrow, supra note 12 at 1103. For critical comment, see Asch and Macklem, supra note 28.

K. McNeil 
appropriate for Canada. Canadian definitions of these concepts must take into account not only our federal system and the Charter of Rights and Freedoms, but also the presence of Aboriginal peoples with governments and laws which have as much claim to legitimacy as the federal and provincial governments and laws. In Canada, parliamentary sovereignty therefore has to be redefined so that legislative jurisdiction is divided among the federal, provincial, and Aboriginal governments. The rule of law must also be redefined to include Aboriginal laws, as well as the common law and federal and provincial legislation. To cling to the old notions of parliamentary sovereignty and the rule of law is to perpetuate outdated and unacceptable colonial attitudes.

For these new definitions to be meaningful, s. 35(1) has to be interpreted as creating a constitutional space for Aboriginal governments and laws. The jurisdiction these governments can exercise within that space would extend to all components of the Aboriginal and treaty rights that the section recognizes and affirms, which, as we have seen, probably include all aspects of Aboriginal life. What the Aboriginal peoples have to do if they want to exercise their jurisdiction is to fill this constitutional space with Aboriginal laws. To the extent that these laws, whether customary or legislative in nature, are already in place, the task is simply to act on them and demonstrate their existence. Where they are not in place, Aboriginal peoples have the option of making them by exercising their inherent right of selfgovernment. ${ }^{152}$ Failing that, however, federal laws infringing their Aboriginal and treaty rights which meet the justificatory test will continue to apply to them due to the decision in Sparrow.

To the extent that Aboriginal and treaty rights are adequately regulated by Aboriginal laws, federal laws infringing those rights

152. Because this right is inherent, stemming from the fact that Aboriginal peoples were self-governing nations prior to the colonization of Canada by Europeans, it does not have to be recognized by the Canadian Constitution. All that is necessary for it to flourish and grow is to provide a constitutional space where that can happen, which, on the argument presented here, is what s. 35(1) has done. 
cannot apply to them. ${ }^{153}$ This conclusion flows from the Sparrow decision. As we have seen, before federal laws are allowed to infringe Aboriginal and treaty rights, the Supreme Court said a valid legislative objective must exist. Moreover, that objective has to be pursued in a manner which infringes those rights as little as possible. But if an Aboriginal people is already regulating its own rights in a way which is consistent with the legislative objective, there can be no need, and therefore no justification, for the federal laws to apply. ${ }^{154}$

In the context of the fishing rights which were in question in Sparrow, for example, if the Musqueam had shown that they had laws which adequately regulated the fishing activities of the members of their Nation, there would be no reason for the federal fishery regulations to apply to them. ${ }^{155}$ In those circumstances, an attempt by the federal government to try to justify theapplication of its own regulations would probably fail. The government might nonetheless attempt to show that, however adequately the Musqueam were regulating their fishing, management of the resource as a whole required a comprehensive regulatory scheme, with priority given to Aboriginal users. But even if that were so, it would not necessarily mean that the Sparrow test of justification had been met so that the federal regulations would displace those of the Musqueam Nation. The Sparrow test, it should be recalled, can require consultation with Aboriginal people before regulatory measures are applied to them. ${ }^{156}$ It is therefore suggested that, in this situation, the federal government would be under an obligation to discuss its

153. A fortiori, provincial laws would not apply either, even if the Sparrow test can be used to justify them in the absence of Aboriginal laws: see supra note 23 .

154. For a variation on this approach, see Slattery "First Nations and the Constitution", supra note 2, especially at 282-283.

155. The burden of proving Aboriginal laws appears to be on the people alleging them, as common law courts do not initially take judicial notice of them. On proof of Aboriginal customary laws, see: Angu v. Attah (1916), P.C. Gold Coast 1874-1928, 43 at 44; Effuah Amissah v. Effuah Krabah (1936), 2 W.A.C.A. 30 (P.C.) at 31; In Re Bed of Wanganui River, [1955] N.Z.L.R. 419 (C.A.) at 432.

156. Sparrow, supra note 12 at 1119. See also R. v. Bones, [1990] 4 C.N.L.R. 37 (B.C. Prov. Ct.) at 44. 
conservation plans with the Musqueam Nation, and try to arrive at a negotiated solution. This cooperative approach could result in a treaty, which each party would agree to implement. In this way, the right of the Musqueam Nation to govern fishing by its members would be respected, and at the same time the federal government's objective of comprehensively regulating the fishery would be met. ${ }^{157}$

\section{Conclusion}

Decolonization of the Canadian Constitution involves envisaging space for Aboriginal governments to exercise their inherent powers, which can be done by interpreting s. 35(1) in an expansive way. While avoiding the jurisdictional vacuum which the Supreme Court apparently feared in Sparrow, this approach is consistent with the justificatory test which the Court laid down in that case. Moreover, it empowers the Aboriginal peoples to take charge of their own communities at whatever pace they choose. Selfgovernment is neither withheld from nor forced upon them. Some Aboriginal peoples might choose to exercise extensive selfgovernment powers immediately, while others might choose to wait until they feel better prepared. The process could be a stepby-step one, permitting an Aboriginal people to gain confidence and expertise in one area, before gradually extending its jurisdiction into other fields. This would allow for both stability and growth. But most importantly of all, it would provide a way to acknowledge immediately, without more constitutional haggling, that Aboriginal governments have a rightful place in the Canadian Constitution.

157. If a negotiated agreement could not be reached, the validity of the federal regulations could be tested in court in accordance with the Sparrow test. In that event, the good faith of each of the parties in the negotiations would be an important factor to consider. It would therefore be in the interest of both parties to negotiate sincerely. 